\title{
KONFERENCJA NAUKOWA OKOLICE ZEGADŁOWICZA
}

(Sucha Beskidzka, 10-12 maja 2017 r.)

JOANNA KULCZYŃSKA-KRUK*

W dniach 10-12 maja 2017 roku w Suchej Beskidzkiej odbyła się konferencja naukowa Okolice Zegadłowicza zorganizowana przez Instytut Filologii Polskiej Uniwersytetu Pedagogicznego w Krakowie, Wydział Polonistyki Uniwersytetu Jagiellońskiego oraz Fundację „Czartak” w Gorzeniu Górnym. Obrady miały miejsce we wnętrzach renesansowego zamku, który jest siedzibą Muzeum Miejskiego.

Referenci, wśród których znajdowali się literaturoznawcy i historycy, reprezentowali liczne ośrodki akademickie: Uniwersytet Pedagogiczny w Krakowie, Uniwersytet Jagielloński, Uniwersytet Warszawski, Uniwersytet Wrocławski, Uniwersytet Śląski, Uniwersytet Ostrawski, Uniwersytet Kazimierza Wielkiego w Bydgoszczy, Akademię Jana Długosza w Częstochowie oraz Bibliotekę Narodową, Instytut Dialogu Międzykulturowego im. Jana Pawła II w Krakowie, Muzeum Miejskie w Wadowicach i Muzeum Tradycji Niepodległościowej Ziemi Wadowickiej im. 12 Pułku Piechoty.

Przedstawione przez prelegentów wyniki badań dotyczyły dorobku poetyckiego, dramatycznego, prozatorskiego oraz publicystycznego Zegadłowicza. Badacze zwrócili uwagę na kilka zasadniczych problemów, do których należą między innymi inspiracje, mediacje i recepcja tekstów. Wokół tych kwestii powstał interesujący dyskurs na temat relacji między poezją Karola Wojtyły a twórczością Zegadłowicza. Polemiczne stanowisko wobec niektórych ustaleń Stanisława Dziedzica omawiającego „Czartakowski świat” w sonetach Wojtyły oraz Marty Burghardt opisującej wpływ Zegadłowicza na twórczość literacką autora Magnificat zajęła Zofia Zarębianka. Badaczka zakwestionowała między innymi zasadność traktowania związków biograficznych oraz obecnej w tekstach obu autorów stylizacji językowej (z wykorzystaniem gwary właściwej dla wspólnego miejsca pochodzenia) jako podstawy dla tezy o bezpośrednim oddziaływaniu autora Kolędziołek na wczesną twórczość Wojtyły. Inspiracje literackie interesowały także Damiana W. Makucha, który wykazał znaczenie twórczości dziewiętnastowiecznych prozaików - Kraszewskiego i Prusa - dla późnego pisarstwa Zegadłowicza na przykładzie powieści Martwe morze. O powojennej adaptacji niedokończonego dramatu Domek $z$ kart w reżyserii Erwina Axera mówiła Krystyna Latawiec. Recepcję twórczości Zegadłowicza w Czechach przedstawiła Urszula Kolberová, która wyniki swojej pracy dopełniła obszernym zestawieniem bibliograficznym zawierającym przekłady, artykuły i recenzje.

Tytułowe okolice Zegadłowicza obejmują przestrzeń geograficzną Beskidu, jego przyrodę $i$ architekturę. Przedstawione w świetle geo- i etnopoetyki literackie krajobrazy były tematem wystąpień Marii Jolanty Olszewskiej analizującej misteria balladowe oraz Jacka Rozmusa, który zwrócił uwagę na rangę szczegółów, takich jak drzewa, kamienie i kapliczki przydrożne, postrzeganych jako „sygnatury pamięci”. Magdalena Baran, opisująca sposób kształtowania przez Zegadłowicza

\footnotetext{
* Joanna Kulczyńska-Kruk - doktorantka, Wydział Polonistyki UJ.
} 
mityczno-geograficznej przestrzeni Beskidów, wskazała na kreacyjny doń stosunek poety oraz rolę, jaką pełni w niej konkret topograficzny. Andrzej S. Dyszak podjął badania nad językowym obrazem przyrody usytuowanym w przestrzeni geograficznej zawierającej się między Wołkowicami a Porębą Murowaną (Zmory). Filozoficzny i zmysłowy aspekt świata przyrody przedstawiony przez Zegadłowicza w czwartej części tetralogii Pieśni Niemotworza pod tytułem Podsłuchy omówiły Katarzyna Małgowska i Katarzyna Wądolny-Tatar, która skoncentrowała uwagę na sensualnym aspekcie poetyckiej mikrologii. Wszechobecny w poezji autentystów i regionalistów mit ziemi był z kolei tematem rozważań Katarzyny Niesporek, która, przywołując Pieśn o Ślasku, zwróciła uwagę na odmienność krajobrazu, w jakim mit ów znalazł realizację - pola uprawne zastąpił obraz górniczych wyrobisk i hut.

Estetyczne i artystyczne źródła twórczości i autokreacji Zegadłowicza były przedmiotem analiz Henryka Czubały (Zmory i motory - źródła twórczości Emila Zegadłowicza) i Bogusława Gryszkiewicza (Emil Zegadłowicz - medytacja nad profilem artysty. Wizualne parateksty i paratekstualna konstrukcja autorstwa).

Związki z artystami plastykami i mistrzami typograficznego rzemiosła interesowały Elżbietę Hurnik, która swoje wystąpienie poświęciła współpracy Zegadłowicza ze Stefanem Żechowskim, jak również Ewę Bartos analizującą Gawędę poety z typografem. Do źródeł sięgnęła Anna Krajewska, która omówiła znajdującą się w księgozbiorze Biblioteki Narodowej korespondencję Zegadłowicza (13 listów) i Samuela Tyszkiewicza (2 odpisy listów) w sprawie wydania w Oficynie Florenckiej Tyszkiewiczów we Florencji drugiej części tetralogii Pieśni Niemotworza pod tytułem Podkowa na progu (1932).

Afektywny charakter twórczości Zegadłowicza, stanowiący swoisty rodzaj strategii literackiej, potwierdza też rzeczywista, szczególna wrażliwość pisarza na drugiego człowieka. Kwestie etyczne i estetyczne były dla pisarza równie ważne, co poświadczają wyniki badań Joanny Kulczyńskiej-Kruk, która zinterpretowała trzecią część Pieśni Niemotworza pod tytułem Światła w okopach w kontekście pokoleniowego doświadczenia wojennego. Wrażliwość Zegadłowicza na krzywdę ujawnia się także w prozie. Oskar Meller opisał destrukcyjne oddziaływanie niektórych praktyk pedagogicznych na psychikę bohaterów powieści Zmory. W nieco innym kontekście ukazał problem systemowej opresji Adam Kowalczyk, który swoją wypowiedź skoncentrował na kategoriach komizmu i czarnego humoru.

Krąg tematów i wątków uczuciowych poszerzają wyznania aktorki, Stanisławy Wysockiej, zawarte w listach do Emila Zegadłowicza, o których mówił Stanisław Stabro oraz wiersze Adama Ziemianina poświęcone żonie, Marii, wnuczce Zegadłowicza, przedstawione przez Marka Karwalę.

Liryzm i emocjonalne, subiektywne widzenie świata charakteryzuje też Balladęo wierzbach pośród których przemkną duch matki - utwór Zegadłowicza, który Marian Kisiel przyporządkował do grupy tekstów współtworzących mit autobiograficzny poety. Badacz zwrócił uwagę na istotną w przypadku realizacji scenicznej dramatyzację oraz muzyczność tekstu. Foniczność ballad Zegadłowicza interesowała również Włodzimierza Próchnickiego, który, sięgając do korzeni gatunku - pieśni ludowej, wskazał w realizacjach Powsinogów beskidzkich elementy retoryczne i meliczne, podkreślając ich znaczenie dla modelowania postawy odbiorcy.

$\mathrm{Na}$ temat realnego zaangażowania się pisarza w kwestie społeczne i kulturowe wypowiedział się Tadeusz Bujnicki, który poddał badaniom teksty publicystyczne Zegadłowicza, zwracając uwagę na istotny w życiu poety akces do formacji lewicowych.

Badania literaturoznawców wsparli historycy. O pracy artystycznej, jej recepcji oraz działalności kulturotwórczej pisarza w wadowickim środowisku mówił Marcin Witkowski, natomiast Michał Siwiec-Cielebon skomentował Skróty kronikarskie, które Zegadłowicz napisał w pierwszych dniach hitlerowskiej agresji na Polskę. 
Dzięki uprzejmości dyrekcji Muzeum Miejskiego w Suchej Beskidzkiej uczestnicy konferencji zapoznali się z historią zamku. Wzięli też udział w spektaklu Emilowe podsiepki w reżyserii Janiny Błońskiej, w którym wystąpili aktorzy Teatru Entre’ Act. Widowisko odbyło się na terenie parku i dworu będącego siedzibą Muzeum Emila Zegadłowicza w Gorzeniu Górnym. Była to też jedna z ostatnich możliwości obejrzenia wyjątkowej kolekcji sztuki w tym miejscu. Wkrótce podziwiać ją można będzie w salach Muzeum Miejskiego w Suchej Beskidzkiej, które przejmie opiekę nad zbiorami w ramach umowy z Fundacją im. Emila Zegadłowicza. 